\title{
HARMONISASI AGAMA \\ (Studi Kasus Koeksistensi Umat Beragama di Kecamatan Lamasi Kabupaten Luwu)
}

\author{
Siti Miftahul Jannah ${ }^{1}$, Muhammad Nawir ${ }^{2}$ \\ ${ }^{1}$ Pendidikan Sosiologi, Universitas Muhammadiyah Makassar \\ Email: miftahul92@gmail.com \\ ${ }^{2}$ Pendidikan Sosiologi, Universitas Muhammadiyah Makassar \\ Email: nawir@unismuh.ac.id
}

\begin{abstract}
Abstrack. This research is one of the scientific studies that discuss the coexistence or harmonious living side by side with religious people between the Muslim and Christian communities in Lamasi Subdistrict, Luwu Regency which is based on the current phenomenon, in a world that is no exception in Indonesia which is related to problems in the name of religion. . This research provides problems such as the form of coexistence of religious communities in the Lamasi District of Luwu Regency and what is the important role of education in the coexistence of religious people in the Lamasi District of Luwu Regency.

The aim of this research is to discuss the form of coexistence of religious communities in the Lamasi District of Luwu Regency and to understand the important role of education in the coexistence of religious people in the Lamasi District of Luwu Regency. The research method used is descriptive qualitative research, with the aim of describing the phenomenon of religious coexistence between Muslim and Christian communities that is systematic from the facts factual and careful.

The results of this study indicate that the three forms of religious coexistence in Lamasi District can be viewed from the coexistence of religious communities and the government, the coexistence of religious people through culture, and the coexistence of religious communities through education. The coexistence of religious communities and the government is manifested in several roles of the Lamasi Subdistrict government such as socialization about participation, facilitating interfaith dialogue, examining services, filtering false news, and presenting cooperation with religious communities in harmony. While the coexistence of religious communities through culture is implemented through arts, traditional marriages, economic activities, and family systems. And finally, the form of coexistence of religious communities through education is carried out by association between educators and students, giving good role models inviting and practicing. Then the important role of education in the coexistence of religious communities in the Lamasi District who participate through formal education invites schools as a venue for socialization, schools as a forum to commemorate religious holidays, schools as a place for community development, schools as supporting social activities, and schools as Try to be incentive and curative about harmony in society. In addition, the important role of education in the coexistence of religious communities which is manifested in informal education is carried out with three styles of discipline, asking for an autocratic style of discipline, autotarian discipline and a permissive discipline style.
\end{abstract}

Keywords : Harmonization, Coexistence, Religion. 
Abstrak. Penelitian ini adalah salah satu kajian ilmiah yang membahas tentang koeksistensi atau hidup rukun secara berdampingan umat beragama antara masyarakat Islam dan Kristen di Kecamatan Lamasi Kabupaten Luwu yang mana berdasarkan fenomena saat ini, di dunia tak terkecuali di Indonesia terdapat isu konflik yang mengatasnamakan agama. Penelitian ini memberikan batasan masalah yaitu bagaimana bentuk-bentuk koeksistensi umat beragama di Kecamatan Lamasi Kabupaten Luwu dan apa peran penting pendidikan dalam koeksistensi umat beragama di Kecamatan Lamasi Kabupaten Luwu.

Tujuan yang ingin dicapai dalam penelitian ini adalah untuk memahami bentuk koeksistensi umat beragama di Kecamatan Lamasi Kabupaten Luwu serta untuk memahami peran penting pendidikan dalam koeksistensi umat beragama di Kecamatan Lamasi Kabupaten Luwu. Metode penelitian yang digunakan adalah penelitian bersifat kualitatif deskriptif, dengan tujuan menggambarkan fenomena koeksistensi umat beragama antara masyarakat Islam dan Kristen secara sistematis dari suatu fakta secara faktual dan cermat.

Hasil penelitian ini menunjukkan bahwasanya tiga bentuk koeksistensi umat beragama di Kecamatan Lamasi dapat ditinjau dari koeksistensi umat beragama dengan pemerintah, koeksistensi umat beragama melalui budaya, serta koeksistensi umat beragama melalui pendidikan. Koeksistensi umat beragama dengan pemerintah diwujudkan dalam beberapa peran pemerintah Kecamatan Lamasi seperti sosialisasi tentang toleransi, memfasilitasi dialog antaragama, pemerataan pelayanan, filterisasi berita palsu, serta adanya kerjasama dengan umat beragama dalam menjaga keharmonisan. Sedangkan koeksistensi umat beragama melalui budaya diimplementasikan melalui kesenian, adat pernikahan, kegiatan ekonomi, dan sistem kekeluargaan. Dan yang terakhir, bentuk koeksistensi umat beragama melalui pendidikan dilakukan dengan pergaulan antara pendidik dan peserta didik, memberi suri tauladan yang baik serta mengajak dan mengamalkan. Kemudian peran penting pendidikan dalam koeksistensi umat beragama di Kecamatan Lamasi yang diamati melalui pendidikan formal diantaranya sekolah sebagai ajang sosialisasi, sekolah sebagai salah satu wadah untuk memperingati hari raya keagamaan, sekolah sebagai tempat untuk menumbuhkembangkan jiwa toleransi, sekolah sebagai penunjang kegiatan sosial, serta sekolah sebagai upaya prefentif dan kuratif mengenai keharmonisan dalam bermasyarakat. Selain itu peran penting pendidikan dalam koeksistensi umat beragama yang diwujudkan dalam pendidikan informal dilakukan dengan tiga gaya pendisiplinan, diantaranya gaya pendisiplinan autotarif, pendisiplinan autotarian serta gaya pendisiplinan permisif.

Kata Kunci: Harmonisasi, Koeksistensi, Agama.

\section{PENDAHULUAN}

Manusia sejatinya adalah makhluk sosial yang mana tidak bisa bertahan hidup tanpa bantuan orang lain. Manusia dalam kehidupannya memiliki tiga fungsi, yaitu sebagai makhluk Tuhan, makhluk individu, dan makhluk sosial-budaya yang saling berkaitan di mana sebagai makhluk Tuhan memiliki kewajiban untuk mengabdi, sebagai individu harus memenuhi segala kebutuhan pribadinya dan sebagai makhluk sosial-budaya harus hidup berdampingan dengan orang lain dalam kehidupan yang selaras dan saling membantu.

Sebagai konsekuensi masyarakat yang pluralis, masyarakat Indonesia secara geografis dan kultural memiliki kebudayaan yang beragam. Ini realitas pluralisme masyarakat yang merupakan fakta empiris sejarah bangsa. Salah satu bentuk pluralitas tersebut adalah pluralisme agama yang pada dasarnya setiap agama membawa kedamaian dan keselarasan hidup.

Pada hakikatnya agama merupakan suatu nilai sehingga merupakan sumber dari berbagai penjabaran norma yang ada, baik norma hukum, norma moral maupun ibadat yang dilakukan oleh manusia. Namun setiap manusia memiliki kepercayaan yang menjadi landasan dalam memilih agama yang akan diyakini dalam hidupnya. Allah telah mengatakan bahwa manusia itu berbedabeda. Dan sesungguhnya perbedaan itu menjadikan hidup manusia penuh warna dan kayanya budaya dalam bernegaraapabila satu dengan yang lainnya saling menjaga, hidup rukun dan saling menghargai antara perbedaan yang terjadi.

Namun sangat disayangkan, tidak semua elemen menjaga hal itu, sehingga ada toleransi yang mulai hilang dalam memahami perbedaan itu, itulah yang menyebabkan konflik antar agama sering terjadi dikalangan masyarakat luar maupun di Indonesia sendiri. Perbedaan konsepsi di antara agama-agama yang ada adalah sebuah realitas, yang tidak dapat dipungkiri oleh siapa pun. Perbedaan bahkan benturan konsepsi itu terjadi pada hampir semua aspek agama, baik di bidang konsepsi tentang Tuhan maupun konsepsi pengaturan kehidupan. Hal ini dalam prakteknya cukup 
sering memicu konflik fisik antara umat berbeda agama karena adanya truth claim atau klaim kebenaran pada setiap penganutnya.

Disinilah, pentingnya membangun toleransi (tasamuh) antar umat beragama. Dengan toleransi, pluralitas dan perbedaan agama dipandang sebagai sunnatullah yang tidak akan pernah berubah sama sekali dan selamanya, karena merupakan kodrat Tuhan dan kenyataan kehidupan yang tak terbantahkan. Toleransi terhadap pluralitas juga menghendaki sikap saling memahami (mutual understanding), dan saling menghargai (mutual respect).

Di kabupaten Luwu, khususnya di Kecamatan Lamasi mayoritas masyarakatnya menganut dua agama besar, yaitu agama Islam dan agama Kristen. Dalam kajian historisnya, belum pernah terdapat konflik yang mengatas namakan agama baik individualistik maupun kelompok. Namun beberapa bulan terakhir terdapat isu yang dapat membahayakan harmonisasi agama yang sudah terjalin sejak lama. Isu tersebut merupakan isu mengenai pemilihan kepala daerah (PILKADA) yaitu pemilihan bupati Luwu yang mana terdapat dua kandidat yang berbeda agama. Hal ini membuat beberapa oknum melakukan agitasi propaganda dengan cara mengaitkan kegiatan politik dengan isu SARA.

\section{KAJIAN PUSTAKA}

\section{a. Harmonisasi Agama}

Menurut kamus besar bahasa Indonesia (KBBI) harmonisasi adalah upaya pencarian keselarasan. Keselarasan disini memiliki artian bahwa manusia sebagai makhluk sosial sejatinya dituntut untuk hidup secara damai dan berdampingan serta meminimalisir adanya konflik atau perpecahan dalam berbagai aspek misalnya dalam segi hidup beragama. Dapat juga dikataan bahwa harmonisasi merupakan keteraturan sosial yang dapat diartikan sebagai suatu sistem kemasyarakatan, pola hubungan, dan kebiasaan yang berjalan lancar demi tercapainya tujuan masyarakat (Paul B. Horton, 1993). Sementara itu, Sitorus (1997) menegaskan bahwa keteraturan sosial adalah suatu keadaan di mana hubungan-hubungan sosial berlangsung secara selaras, serasi dan harmonis menurut nilai-nilai dan norma-norma yang berlaku. Secara demikian dapat ditegaskan bahwa harmonisasi adalah kondisi dinamis, di mana sendi-sendi kehidupan bermasyarakat berjalan seara tertib dan teratur sehingga tujuan kehidupan bermasyarakat dapat tercapai.

Berdasarkan sudut pandang kebahasaan, agama dianggap sebagai kata yang berasal dari bahasa sangsekerta yang artinya "tidak kacau". Agama diambil dari dua akar suku kata, yaitu a yang berarti tidak dan gama yang berarti kacau. Menurut inti maknanya yang khusus, kata agama dapat disamakan dengan kata religion dalam bahasa Inggris, religie dalam bahasa Belanda keduanya berasal dari bahasa Latin, religio, dari akar kata religare yang berarti mengikat. Adapun agama dalam pengertian sosiologi adalah gejala sosial yang umum dan dimiliki oleh seluruh masyarakat yang ada didunia ini, tanpa terkecuali. la merupakan salah satu aspek dalam kehidupan sosial dan bagian dari sistem sosial suatu masyarakat. Agama juga bisa dilihat sebagai unsur dari kebudayaan suatu masyarakat disamping unsur-unsur yang lain, seperti kesenian, bahasa, sistem mata pencaharian, sistem peralatan, dan sistem organisasi sosial.

\section{b. Agama dan Masyarakat}

Menurut para ilmuan sosial, kehidupan manusia yang terbentang sepanjang sejarah selalu dibayang-bayangi oleh apa yang disebut agama. Bahkan, dalam kehidupan sekarang pun dengan kemajuan teknologi supramodern manusia tak luput dari agama. Agama-agama lahir pada babak sejarah pramodern, sebelum masyarakat dan dunia diwarnai perkembangan pesat dan teknik. Peter L. Berger (1969:268) melukiskan agama sebagai suatu kebutuhan dasar manusia; karena agama merupakan sarana untuk membela diri terhadap segala kekacauan yang mengancam hidup manusia. Hampir semua masyarakat di muka bumi mempunyai agama. Malinowski (1954:17) menyatakan tidak ada bangsa, bagaimanapun primitifnya, yang tidak memiliki agama dan magi. Agama dapat dipandang sebagai kepercayaan dan pola perilaku yang diusahakan oleh suatu masyarakat untuk 
menangani masalah penting yang tidak dapat dipecahkan oleh teknologi dan teknik organisasi yang diketahuinya. Untuk mengatasi keterbatasan itu, orang berpaling kepada manipulasi kekuatan supernatural (Haviland, 1988:193).

Sedangkan menurut Max Weber, determinasi religius atas pola hidup merupakan salah satu determinan etika ekonomi atau etika Protestan. Etika Protestan adalah sebuah konsep dan teori dalam teologi, sosiologi, ekonomi, dan sejarah yang mempersoalkan masalah manusia yang dibentuk oleh nilai-nilai budaya disekitarnya, khususnya nilai agama. Dalam agama Protestan ada ajaran bahwa seorang manusia sudah ditakdirkan sebelumnya sebelum masuk ke surga atau neraka. Hal tersebut ditentukan melalui apakah manusia tersebut berhasil atau tidak dalam perkerjaannya di dunia. Adanya kepercayaan ini membuat agama Protestan bekerja keras untuk meraih sukses.

Membicarakan peranan agama dalam kehidupan sosial menyangkut dua hal yang sudah tentu hubungannya erat dan memiliki aspek-aspek yang terpelihara. Yaitu pengaruh dari cita-cita agama dan etika, agama dalam kehidupan individu dari kelas sosial dan grup sosial, perseorangan dan kolektivitas, dan mencakup kebiasaan dan cara semua unsur asing agama diwarnainya. Yang lainya juga menyangkut organisasi dan fungsi dari lembaga agama sehingga agama dan masyarakat itu berwujud kolektivitas ekspresi nilai-nilai kemanusiaan, yang mempunyai seperangkat arti mencakup perilaku sebagai pegangan individu (way of life) dengan kepercayaan dan taat kepada agamanya. Agama sebagai suatu sistem mencakup individu dan masyarakat, seperti adanya emosi keagamaan, keyakinan terhadap sifat faham, ritus, dan upacara, serta umat atau kesatuan sosial yang terikat terhadap agamanya. Agama dan masyarakat dapat pula diwujudkan dalam sistem simbol yang memantapkan peranan dan motivasi manusianya, kemudian terstrukturnya mengenai hukum dan ketentuan yang berlaku umum, seperti banyaknya pendapat agama tentang kehidupan dunia seperti masalah keluarga, bernegara, konsumsi, produksi, hari libur, prinsip waris, dan sebagainya.

Agama, dalam kaitannya dengan masyarakat, mempunyai dampak positif berupa daya penyatu (sentripental), dan dampak negatif berupa daya pemecah (sentrifugal). Agama yang mempunyai sistem kepercayaan dimulai dengan penciptaan pandangan dunia baru yang di dalamnya konsepsi lama dan pelembagaannya bisa kehilangan dasar adanya. Meskipun ajaran pokok suatu agama bisa bersifat universal, namun mula-mula ditujukan kepada sekelompok orang yang sedikit banyak homogen. Agama menjadi dasar solidaritas kelompok baru yang tertentu. Perpecahan pun timbul manakala adanya penolakan terhadap pandangan hidup lama atau yang berbeda dengan agama. Perpecahan itu timbul disebabkan oleh klaim kebanaran (truth claim) dan sering diekspresikan dalam bentuk-bentuk yang keras tanpa kompromi.

Konsep Koeksistensi

Menurut kamus besar bahasa Indonesia (KBBI) koeksitensi adalah hidup rukun secara berdampingan. Koeksistensi merupakan suatu keadaan ketika dua atau lebih kelompok hidup bersama dengan menghormati perbedaan tiap kelompok dan menyelesaikan konflik antarkelompok tanpa kekerasan. Dasar dari koeksistensi adalah kesadaran bahwa individu dan kelompok berbeda, mencakup perbedaan kelas, etnis, agama, gender, dan pilihan politik. Identitas-identitas kelompok tersebut dapat menjadi sumber konflik. Konsep koeksistensi, dengan demikian, mengurangi kemungkinan perbedaan identitas kelompok yang akan meningkat menjadi konflik yang rumit dan merusak.

Din Syamsuddin (2011) menegaskan bahwa koeksistensi damai adalah keniscayaan bagi masyarakat dunia yang multikultural dan multireligius. Tanpa itu dunia akan dipenuhi konflik. Peradaban dunia menghadapi tantangan serius dengan menggejalanya berbagai bentuk kerusakan akumulatif seperti kemiskinan, kebodohan, ketakadilan, hingga kerusakan lingkungan hidup, dan tsunami kebudayaan. Maka diperlukan langkah bersama umat beragama dunia untuk menanggulanginya. Memang ada faktor-faktor non agama yang mendorong konflik seperti ekonomi, politik. Namun konflik, intoleransi, dan eksklusifisme juga berpangkal pada pemahaman agama yang salah. Maka dari itu, perlu dikembangkan pemahaman yang benar yang menekankan kasih sayang dan kesadaran tentang one humanity, one destiny dan one responsibility. 


\section{Pendidikan}

Definisi pendidikan telah banyak dikemukakan oleh para ahli pendidikan. Dalam Kamus Besar Bahasa Indonesia (1995:232) diyatakan bahwa pendidikan ialah proses pengubahan sikap dan tata laku seseorang atau kelompok orang dalam usaha mendewasakan manusia melalui upaya pengajaran dan pelatihan. Jadi, pendidikan merupakan sebuah proses, yakni proses perubahan perilaku baik individu ataupun sekelompok orang, dengan tujuan untuk membuat individu-individu tersebut dewasa. Maksud dewasa di sini adalah bahwa individu itu mencapai kematangan dalam pikiran dan pandangan. Dalam pengertian ini juga terkandung upaya atau usaha yang dilakukan dalam kegiatan pendidikan, yakni melalui pengajaran dan latihan.Sejalan dengan definisi di atas, Sukmadinata (2004:1) juga mengemukan pendidikan sebagai upaya-upaya, yakni upaya mencerdaskan bangsa, menanamkan nilai-nilai moral dan agama, membina kepribadian, mengajarkan pengetahuan, melatih kecakapan, ketrampilan, memberikan bimbingan, arahan, tuntunan, teladan, dan lain-lain.

Berdasarkan UU No. 2 Tahun 1985 yang berbunyi bahwa tujuan pendidikan yaitu mencerdaskan kehidupan bangsadan mengembangkan manusia yang seutuhnya yaitu yang beriman dan bertakwa kepada Tuhan Yang Maha Esa dan berbudi pekerti luhur, memiliki pengetahuan dan keterampilan, kesehatan jasmani dan rohani, kepribadian yang mantap dan mandiri serta rasa tanggung jawab kemasyarakatan bangsa. Berdasarkan MPRS No. 2 Tahun 1960 bahwa tujuan pendidikan adalah membentuk pancasilais sejati berdasarkan ketentuan-ketentuan yang dikehendaki oleh pembukaan UUD 1945 dan isi UUD 1945.

Pendidikan secara umum mempunyai arti suatu proses kehidupan dalam mengembangkan diri tiap individu untuk dapat hidup dan melangsungkan kehidupan. Sehingga menjadi seorang yang terdidik itu sangat penting.

Sebagaimana yang diungkapkan Daoed Joesoef tentang pentingnya pendidikan: "Pendidikan merupakan segala bidang penghidupan, dalam memilih dan membina hidup yang baik, yang sesuai dengan martabat manusia" Dan tentulah dari pernyataan tersebut kita bisa mengambil kesimpulan bahwa Pendidikan merupakan hal yang sangat penting dan tidak bisa lepas dari kehidupan.

Didalam UU No.20/2003 tentang sistem pendidikan Nasional, tercantum pengertian pendidikan: "pendidikan adalah usaha sadar dan terencana untuk mewujudkan suasana belajar dan proses pembelajaran agar peserta didik secara aktif mengembangkan potensi dirinya sehingga memiliki kekuatan spiritual keagamaan, pengendalian diri, kepribadian, kecerdasan, akhlak mulia, serta keterampilan yang diperlukan oleh dirinya, masyarakat, banga dan negara."

\section{METODE PENELITIAN}

Jenis penelitian yang digunakan adalah jenis penelitian kualitatif. Penelitian kualitatif adalah suatu proses penelitian dan pemahaman yang berdasarkan pada metodologi yang menyelidiki suatu fenomena sosial dan masalah manusia. Dalam tradisi penelitian kualitatif, proses penelitian dan ilmu pengetahuan tidak sesederhana apa yang terjadi pada penelitian kuantitatif, karena sebelum hasil-hasil penelitian kualitatif memberi sumbangan kepada ilmu pengetahuan, tahapan penelitian kualitatif melampaui berbagai tahapan berpikir kritis ilmiah, yang mana seorang peneliti memulai berpikir secara induktif, yaitu menangkap berbagai fakta atau fenomena-fenomena sosial, melalui pengamatan di lapangan, kemudian menganalisisnya dan kemudian berupaya melakukan teorisasi berdasarkan apa yang diamati itu. Pada pendekatan ini, penulis menggunakan desain kualitatif deskriptif.

Penelitian ini berlokasi di Kelurahan Lamasi, Kecamatan Lamasi, Kabupaten Luwu, Provinsi Sulawesi Selatan karena di dasarkan pada beberapa pertimbangan, yaitu Kelurahan Lamasi adalah sebuah daerah yang mana masyarakatnya termasuk kedalam golongan masyarakat pluralis yang masih menjaga toleransi keagaman. Informan penelitian di dalam penelitian kualitatif berkaitan dengan bagaimana langkah yang ditempuh peneliti agar data atau informasi dapat diperolehnya. Karena itu di dalam bahasan ini yang paling penting adalah peneliti "menentukan" informan dan bagaimana peneliti "mendapatkan" informan. Dari kedua usaha tersebut di atas, maka dalam 
penelitian kualitatif ini penulis menggunakan 12 informan yang terdiri: 4 informan dari pemerintah setempat, 4 informan dari masyarakat Lamasi, dan 4 informan dari tenaga pendidik. Penelitian ini difokuskan pada harmonisasi umat beragama di Kecamatan Lamasi Kabupaten Luwu.

\section{HASIL PENELITIAN}

Dalam teori sentimen kemasyarakatan yang dikemukakan oleh Emile Durkheim, agama muncul karena adanya suatu getaran, suatu emosi yang ditimbulkan dalam jiwa manusia sebagai akibat dari pengaruh rasa kesatuan sebagai sesama warga masyarakat dan dipandang sebagai sistem kepercayaan yang diwujudkan dalam perilaku sosial tertentu. Hal ini berkaitan dengan bentuk koeksistensi umat beragama di Kecamatan Lamasi yang memiliki tujuan sebuah keharmonisan dalam beragama yang diwujudkan dengan adanya sikap saling menghargai dan menghormati antar umat beragama, baik umat Islam maupun Kristen dan adanya hubungan timbal balik antara umat beragama dengan pemerintah setempat.

Perilaku individu dan sosial digerakkan oleh kekuatan dari dalam yang didasarkan pada nilainilai ajaran agama yang menginternalisasi sebelumnya. Karena itu, keagamaan yang bersifat subjektif dapat diobjektifkan dalam pelbagai macam ungkapan, dan ungkapan-ungkapan tersebut mempunyai struktur tertentu yang dapat dipahami. Dan untuk menjaga keseimbangan struktur tersebut, diperlukan berbagai macam upaya yang mana salah satunya yaitu melalui peran penting pendidikan khususnya di Kecamatan Lamasi serta pemenuhan beberapa syarat dalam upaya pengharmonisasian di antaranya norma-norma sosial, nilai-nilai sosial, dan lembaga sosial sehingga membentuk adanya keteraturan sosial sebagaimana yang diungkapkan oleh Paul B. Horton, keteraturan sosial diartikan sebagai suatu sistem kemasyarakatan, pola hubungan, dan kebiasaan yang berjalan lancar demi tercapainya tujuan masyarakat.

Selain itu melihat dari hasil penelitian mengenai bentuk koeksistensi umat beragama di Kecamatan Lamasi dan kaitannya dengan teori struktural fungsional dari Talcott Parsons, sumbangan agama terhadap pemeliharaan masyarakat ialah memenuhi sebagian di antara kebutuhan masyarakat. Ketika fungsi agama yang dimana esensi semua agama pada dasarnya merujuk kepada perdamaian, kemudian umat beragama di Kecamatan Lamasi sadar akan fungsi tersebut, maka dengan adanya kesadaran akan fungsi tersebut masyarakat mampu mengatasi perbedaanperbedaan sehingga masyarakat tersebut dipandang sebagai suatu sistem yang secara fungsional terintegrasi dalam sebuah keseimbangan. Dengan demikian masyarakat Lamasi merupakan kumpulan sistem-sistem sosial yang satu sama lain berhubungan dan saling memiliki ketergantungan.

Fungsi agama dalam pengukuhan nilai-nilai, bersumber pada kerangka acuan yang bersifat sakral (Emile Durkheim), maka normanya pun dikukuhkan dengan sanksi-sanksi sakral. Dalam setiap masyarakat sanksi sakral mempunyai kekuatan memaksa istimewa, karena ganjaran dan hukumannya bersifat duniawi dan supramanusiawi serta ukhrowi. Fungsi agama di bidang sosial adalah fungsi penentu, di mana agama menciptakan suatu ikatan bersama, baik di antara anggotaanggota beberapa masyarakat maupun kewajiban-kewajiban sosial yang membantu mempersatuan mereka salah satunya merujuk kepada bentuk koeksitensi umat beragama di Kecamatan Lamasi melaui budaya, yang mana kesenian, adat pernikahan, kegiatan ekonomi, dan sistem kekeluargaan menjadi tali pengikat dalam mengimplementasikan konsep toleransi. Fungsi agama sebagai sosialisasi individu ialah individu pada saat dia menjadi dewasa, memerlukan suatu sistem nilai sebagai semacam tuntunan umum untuk mengarahkan aktivitasnya dalam masyarakat, dan berfungsi sebagai tujuan akhir pengembangan kepribadiannya. Atas dasar tersebut masyarakat Lamasi berupaya untuk mendidik anak-anaknya sejak dini dengan menggunakan gaya pendisiplinan autotarif, gaya pendisiplinan autotarian, dan gaya pendisiplinan permisif, yang mana gaya pendisiplinan tersebut memiliki kelebihan dan kekurangan masing-masing.

Mekanisme sosial lain, selain dari sumber ajaran agama itu sendiri, ialah kaitannya dengan perilaku ekonomi khususnya di Kecamatan Lamasi. Menurut Max Weber, determinasi religius atas pola hidup merupakan salah satu determinan etika ekonomi. Tentu saja cara hidup yang ditentukan 
secara religius dengan sendirinya sangat dipengaruhi oleh faktor-faktor ekonomi dan politik yang beroperasi dalam batas-batas geografis, politik, sosial dan nasional yang berlaku.

Sejalan dengan perspektif tersebut, dapat dikatakan bahwa agama merupakan salah satu bentuk legitimasi yang paling efektif. Agama merupakan semesta simbolik yang memberi makna pada kehidupan manusia, dan memberikan penjelasan yang paling komprehensif tentang seluruh realitas. Agama merupakan naungan sakral yang melindungi manusia dari situasi kekacauan (chaos). Bagi para penganutnya, agama berisikan ajaran-ajaran mengenai kebenaran tertinggi dan mutlak tentang eksistensi manusia dan petunjuk-petunjuk untuk hidup selamat di dunia dan di akhirat, yaitu sebagai manusia yang bertakwa kepada Tuhannya, beradab dan manusiawi, yang berbeda dari caracara hidup hewan atau makhluk lainnya. Sebagai sistem keyakinan, agama bisa menjadi bagian dan inti dari sistem nilai yang ada dalam kebudayaan dari masyarakat, dan menjadi pendorong atau penggerak serta pengontrol bagi tindakan anggota masyarakat tertentu untuk tetap berjalan sesuai dengan nilai-nilai kebudayaan dan ajaran agamanya. Ketika pengaruh ajaran agama sangat kuat terhadap sistem nilai dari kebudayaan masyarakat yang bersangkutan, maka sistem nilai kebudayaan itu terwujud sebagai simbol suci yang maknanya bersumber pada ajaran agama yang menjadi kerangka acuannya.

Dalam keadaan demikian, secara langsung atau tidak langsung, etos yang menjadi pedoman dari koeksistensi umat beragama yang ada dalam masyarakat Lamasi (pemerintah, budaya dan pendidikan), dipengaruhi, digerakkan, dan diarahkan oleh berbagai sistem nilai yang sumbernya adalah agama yang dianutnya dan terwujud dalam kegiatan para warga masyarakatnya sebagai tindakan dan karya yang diselimuti oleh simbol-simbol suci. Keyakinan agama yang sifatnya pribadi dan individual bisa berupa tindakan kelompok. Keyakinan itu menjadi sosial disebabkan oleh hakikat agama itu sendiri yang salah satu ajarannya adalah hidup dalam kebersamaan dengan orang lain.

\section{PENUTUP}

Sebagai umat yang beragama harus sadar akan kedudukannya sebagai hamba Allah di atas muka muka bumi ini yaitu melaksanakan apa yang telah diperintahkannya dan meninggalkan semua larangannya. Dalam hal ini membutuhkan peranan dari berbagai elemen masyarakat, seperti pemerintah dan pemuka agama sebagai pemimpin umat yang memengang kontrol dalam menjaga keharmonisasian khususnya di Kecamatan Lamasi.

Setiap umat beragama tanpa terkecuali memiliki tanggung jawab moral untuk mengarahkan untuk taat kepada Tuhan dan mengetahui tugas-tugasnya sebagai khalifah Allah yang bertugas memelihara alam ini. Sehingga terwujud kemakmuran di atas muka bumi ini. Hal ini dapat dimulai sejak dini saat anak-anak mulai mengenal pendidikan, baik pendidikan formal maupun informal. Tenaga pendidik bukan hanya guru, namun yang terpenting adalah orang tua karena orang tua memiliki waktu yang lebih banyak bersama anak-anaknya.

\section{DAFTAR PUSTAKA}

Aisyah, Siti dkk. (2008). Perkembangan dan Konsep Dasar Pengembangan Anak Usia Dini. Jakarta : Universitas Terbuka.

Ardiansyah. (2013). Kerukunan Umat Beragama Antara Masyarakat Islam dan Kristen di Kelurahan Paccinongang Kecamatan Somba OPU Kabupaten Gowa. Skripsi tidak diterbitkan. Makassar : UIN Alauddin.

Arifin, Jamaluddin dkk. (2015). Buku Pedoman Skripsi (Khusus Bagi Mahasiswa Bidang Kajian Penelitian Sosial Budaya). Makassar : Program Studi Pendidikan Sosiologi Fakultas Keguruan Dan Ilmu Pendidikan Universitas Muhammadiyah Makassar.

Bungin, Burhan. (2007). Penelitian Kualitatif. Jakarta : Prenada Media Group.

Departemen Pendidikan Indonesia. (2008). Kamus Besar Bahasa Indonesia (KBBI). Jakarta : Balai Pustaka. 
Duverger, Maurice. (2003). Sosiologi Politik. Jakarta : Raja Grafindo Persada.

Hakim, Suparlan Al. (2015). Pengantar Studi Masyarakat Indonesia. Malang : Madani.

Haryanto, Sindung. (2016). Sosiologi Agama. Yogyakarta : Ar-Ruzz Media.

Ismardi dan Arisman. (2014). Meredam Konflik Dalam Upaya Harmonisasi Antar Umat Beragama.

Jurnal Toleransi : Media Komunikasi Umat Bergama, Vol.6, No.2 Juli-Desember. Jahar, Saepudin Asep. (2013). Sosiologi Sebuah Pengantar: Tinjauan Pemikiran Sosiologi Perspektif Islam. Tangerang : Sejahtera Kita.

Kahmad, Dadang. (2009). Sosiologi Agama. Bandung : Remaja Rosdakarya.

Kementrian Agama Republik Indoesia. (2010). Al-Qur'an dan Terjemahan. Sukoharjo : Madina Qur'an.

Maryama, Ima. (2011). Al-Qur'an dan Kerukunan Hidup Umat Beragama. Jakarta : Elex Media Komputindo.

Noor Irwan, dkk. (2015). Pemekaran Kecamatan dalam Peningkatan Pelayanan Kependudukan. Jurnal Administrasi Publik : Fakultas IImu Administrasi, Universitas Brawijaya Malang, Vol.1, No.3.

Percepatan Pembangunan Sanitasi Permukiman. (2010). Buku Putih Sanitasi Kabupaten Luwu. http://ppsp.nawasis.info/dokumen/perencanaan/sanitasi/ pokja/bp/kab.luwu/BUKU\%20PUTIH\%20BAB\%20II LUWU.pdf (Diakses pada tanggal 26 Juli 2018)

Prawira, Atmaja Purwa. (2012). Psikologi Pendidikan dalam Perspektif Baru. Malang : Ar-Ruzz Media.

Ritzer George. (2014). Sociology : A Multiple Paradigm Science.(Diterjemahkan oleh Alimandan, Jakarta : Rajawali Pers).

Ritzer, George. (2012). Teori Sosiologi : Dari Sosiologi Klasik Sampai Perkembangan Terakhir Postmodern. Yogyakarta : Pustaka Pelajar.

Setiadi, Elly M dkk. (2017).IImu Sosial dan Budaya Dasar. Jakarta : Fajar Interpratama Mandiri.

Sintiani, Ani Ayu. (2014). Harmonisasi Kerukunan Beragama (Studi Keberadaan Kong Miao Lithang MAKIN Banjar di Lingkungan Masyarakat Muslim Kota Banjar). Skripsi tidak diterbitkan. Bandung : UIN Sunan Gunung Djati.

Soelaeman, M. Munandar. (2015). IImu Sosial Dasar, Teori dan Konsep IImu Sosial. Bandung : Refika Aditama.

Sugiono. (2008). Metode Penelitian Pendekatan Kuaitatif Kuantitatif. Bandung : Alfabeta.

Sukmadiata, N.S. (2004). Kurikulum dan Pembelajaran Kompetensi. Bandung : Yayasan Kusuma Karya.

Susetyo, Benny. (2005). Politik Pendidikan Penguasa. Yogyakarta : Pelangi Aksara.

Tilaar, HAR. (2012). Perubahan Sosial dan Pendidikan (Pengantar Pedagogik Transformatif untuk Indonesia). Jakarta : Rineka Cipta.

Tischler, Henri L. (1990). Introduction to Sociology. Chicago : Holt, Rinehart and Winston.

Ulwan, Khemas Aulia. (2017). Harmonisasi Hindu dan Muslim : Studi Atas Partisipasi Muslim Dalam Perayaan Ogoh-ogoh Agama Hindu Di Cakranegara Mataram. Skripsi tidak diterbitkan. Jakarta : UIN Syarif Hidayatullah.

Upe, Ambo. (2010). Tradisi Aliran Dalam Sosiologi : Dari Filosofi Positivistik Ke Post Positivistik. Jakarta: PT Raja Grafindo Persada.

Weber, Max. (1946). Essays in Sociology, Oxford University Press. (Diterjemahkan oleh Noorkholish, Yogyakarta : Pustaka Pelajar, 2009). 